\title{
Anticoagulant, Antioxidant and Antitumor Activities of Heterofucans from the Seaweed Dictyopteris delicatula
}

\author{
Kaline Dantas Magalhaes ${ }^{1,2, \dagger}$, Leandro Silva Costa ${ }^{1,3, \dagger}$, Gabriel Pereira Fidelis ${ }^{1}$, \\ Ruth Medeiros Oliveira ${ }^{1}$, Leonardo Thiago Duarte Barreto Nobre ${ }^{1}$, Nednaldo Dantas-Santos ${ }^{1,2}$, \\ Rafael Barros Gomes Camara ${ }^{1}$, Ivan Rui Lopes Albuquerque ${ }^{1,2}$, Sara Lima Cordeiro ${ }^{1}$, \\ Diego Araujo Sabry ${ }^{1}$, Mariana Santana Santos Pereira Costa ${ }^{1}$, Luciana Guimaraes Alves ${ }^{1}$ and \\ Hugo Alexandre Oliveira Rocha ${ }^{1,2, *}$
}

1 Laboratory of Biotechnology of Natural Polymers (BIOPOL), Department of Biochemistry, Federal University of Rio Grande do Norte (UFRN), 59020-100 Natal-RN, Brazil;

E-Mails: kdmbio@yahoo.com.br (K.D.M.); leandro-silva-costa@hotmail.com (L.S.C.); gabrielfideliss@gmail.com (G.P.F.); rmo_85@ hotmail.com (R.M.O.);

leo_dnobre@yahoo.com.br (L.T.D.B.N.); nednaldod@ hotmail.com (N.D.-S.); rafael_bgc@yahoo.com.br (R.B.G.C.); ivan.rui@click21.com.br (I.R.L.A.); sara-cordeiro@hotmail.com (S.L.C.); popoh_diego@hotmail.com (D.A.S.); marispc_bio@yahoo.com.br (M.S.S.P.C.); lucianagalves@hotmail.com (L.G.A.)

2 Health Post-Graduate Program, Federal University of Rio Grande do Norte (UFRN), 59020-100 Natal-RN, Brazil

3 Federal Institute of Education, Science and Technology of Rio Grande do Norte (IFRN), 59200-000 Santa Cruz-RN, Brazil

$\dagger$ These authors contributed equally to the work.

* Author to whom correspondence should be addressed; E-Mail: hugo@cb.ufrn.br; Tel.: +55-84-32153416 (ext.) 207; Fax: +55-84-32119208.

Received: 9 March 2011; in revised form: 11 April 2011 / Accepted: 19 May 2011 / Published: 23 May 2011

\begin{abstract}
In the present study, six families of sulfated polysaccharides were obtained from seaweed Dictyopteris delicatula by proteolytic digestion, followed by acetone fractionation and molecular sieving on Sephadex G-100. Chemical analyses demonstrated that all polysaccharides contain heterofucans composed mainly of fucose, xylose, glucose, galactose, uronic acid, and sulfate. The fucans F0.5v and F0.7v at $1.0 \mathrm{mg} / \mathrm{mL}$ showed high ferric chelating activity $(\sim 45 \%)$, whereas fucans $\mathrm{F} 1.3 \mathrm{v}(0.5 \mathrm{mg} / \mathrm{mL})$ showed considerable
\end{abstract}


reducing power, about $53.2 \%$ of the activity of vitamin $\mathrm{C}$. The fucan F1.5v presented the most prominent anticoagulant activity. The best antiproliferative activity was found with fucans F1.3v and F0.7v. However, F1.3v activity was much higher than F0.7v inhibiting almost $100 \%$ of HeLa cell proliferation. These fucans have been selected for further studies on structural characterization as well as in vivo experiments, which are already in progress.

Keywords: fucoidan; brown seaweed; biological activities; sulfated polysaccharides

\section{Introduction}

Marine seaweeds (green, red and brown) are the most abundant source of non-mammalian anticoagulant sulfated polysaccharides in nature. Some structural similarities between sulfated seaweed polysaccharides and heparin led several groups to study algal polysaccharides as antithrombotic [1], anti-adhesive [2], antitumoral [3], antiviral [4], anticoagulant, antioxidant, proangiogenic, anti-inflammatory, anthelmintic compounds [5,6]. The well known sulfated polysaccharides from red seaweed are homogalactans [7] and from brown algae are $\alpha$-L-fucose-containing sulfated homo and heteropolysaccharides [6] called fucan and fucoidan, respectively. On the other hand, green algae synthesize several kinds of sulfated homo and heteropolysaccharides [6].

The Brazilian's northeast coast has a great variety of seaweeds. However, few pharmacognostical and pharmacological investigations about these seaweeds are carried out to identify new drugs or to find new structures for the development of novel therapeutic agents for the treatment of human diseases such as cancer and infectious diseases [8].

In Brazil, the brown seaweed Dictyopteris delicatula is common along the northeast coast. Recently, we obtained a polysaccharide-rich extract from D. delicatula, which exhibited assorted biological activities, including anticoagulant, antiproliferative and antioxidant activities [9]. However, the biological activities of the purified sulfated polysaccharides from $D$. delicatula have not been investigated.

On the basis of these considerations, the purpose of the present study was to obtain sulfated polysaccharides from $D$. delicatula and to evaluate their anticoagulant, antioxidant and antiproliferative activities in vitro. Our results show several noteworthy differences in the activities of polysaccharides from $D$. delicatula, which are likely connected to differences in the chemical structure of these compounds. This work was directed to the selection of the most active sulfated polysaccharide samples to be studied further as potential novel drugs for thrombosis, antitumor and/or antioxidant therapy.

\section{Results and Discussion}

\subsection{Chemical Analysis}

Using a methodology that combined proteolysis and acetone precipitation we obtained six polysaccharides preparations from brown seaweed $D$. delicatula. The addition of increasing volumes of acetone gradually decreased the dielectric constant of water, thereby promoting different sulfated polysaccharide precipitation rates. Acetone separates polysaccharides by the way in which the charges of these polymers interact with water. Thus, those that interact more with water are the last to 
precipitate. Each fraction was subjected to molecular sieving on Sephadex G-100, monitored for total sugar and metachromasia. Each fraction had a single peak, which indicates that each fraction is composed of a unique population of sulfated polysaccharide (Data not shown). The tubes containing the sulfated polysaccharides were pooled and lyophilized, and the sulfated polysaccharides were also named F0.5v; F0.7v; F1.0v; F1.3v; F1.5v and F2.0v respectively.

The chemical analysis of sulfated polysaccharides is summarized in Table 1; sulfate and fucose were found in all polysaccharides. Moreover, other neutral monosaccharides were also found as components of these polymers indicating that that $D$. delicatula synthesizes at least six families of sulfated heterofucans.

Table 1. Chemical composition of sulfated polysaccharides extracted from Dictyopteris delicatula.

\begin{tabular}{|c|c|c|c|c|c|c|c|c|c|c|}
\hline \multirow{2}{*}{ Fucans } & \multirow{2}{*}{$\begin{array}{c}\text { Total } \\
\operatorname{sugar}(\%)\end{array}$} & \multirow{2}{*}{$\begin{array}{c}\text { Sulfate } \\
(\%)\end{array}$} & \multirow{2}{*}{$\begin{array}{l}\text { Sulfate/Total } \\
\text { sugar }(\% / \%)\end{array}$} & \multirow{2}{*}{$\begin{array}{c}\text { Protein } \\
\text { s }(\%)\end{array}$} & \multicolumn{6}{|c|}{ Molar ratio } \\
\hline & & & & & Fuc & Gal & Glc & Man & Xyl & Gluc A \\
\hline $\mathrm{F} 0.5 \mathrm{v}$ & 89.1 & 14.1 & 0.16 & 0.1 & 1.0 & 2.0 & 0.3 & 0.5 & 0.7 & 0.9 \\
\hline $\mathrm{F} 0.7 \mathrm{v}$ & 70.0 & 17.8 & 0.25 & 0.3 & 1.0 & 3.0 & 0.4 & 0.6 & 1.5 & 2.2 \\
\hline $\mathrm{F} 1.0 \mathrm{v}$ & 65.0 & 19.0 & 0.29 & 0.5 & 1.0 & 1.9 & 0.2 & 0.5 & 0.8 & 1.5 \\
\hline $\mathrm{F} 1.3 \mathrm{v}$ & 68.2 & 14.5 & 0.21 & 0.1 & 1.0 & 2.4 & 0.3 & 0.2 & 0.6 & 0.5 \\
\hline $\mathrm{F} 1.5 \mathrm{v}$ & 61.3 & 15.4 & 0.25 & 0.1 & 1.0 & 1.6 & 0.2 & 0.4 & 1.3 & 1.9 \\
\hline $\mathrm{F} 2.0 \mathrm{v}$ & 64.3 & 16.0 & 0.25 & 0.7 & 1.0 & 1.8 & 0.2 & 0.4 & 1.6 & 2.2 \\
\hline
\end{tabular}

Fuc_fucose; Gal—galactose; Glc_glucose; Man—mannose; Xyl—xylose; Gluc A—glucuronic acid.

The heterofucan F1.0v was the polysaccharide with the higher percentage of sulfate (19.0\%) in comparison to other heterofucans. In addition, when the sulfate/total sugar ratio was determinate (Table 1) F1.0v showed the highest ratio, whereas F0.5v presented the smallest ratio. All the polysaccharides showed low protein contamination, which ranged from 0.1 (F0.5v, F1.3v and F1.5v) to $0.7 \%(\mathrm{~F} 2.0 \mathrm{v})$; this is due to the use of the proteolytic enzyme during the method of polysaccharide extraction.

The monosaccharide composition of sulfated polysaccharides is also shown in Table 1. All fractions showed the same constitution on monosaccharides: fucose, galactose, glucose, mannose, xylose and glucuronic acid. The data showed galactose as the main sugar present in the all of the heterofucans, but the amount of this sugar is different in each polymer. In addition, there are differences among the relative proportions of glucuronic acid and xylose observed in different polysaccharides; they are found in greater amounts in F0.7v; F1.5v and F2.0v. On the other hand, the proportion of mannose and glucose did not show higher differences among the heterofucans. Thus, it is clear that the relative amounts of these sugars vary according to the fucan extracted.

Most brown seaweeds synthesize sulfated polysaccharides consisting mainly of sulfated L-fucose with fucose content about 34-44\%. They may as well contain small portions of galactose, mannose, glucose, xylose and glucuronic acid [5]. However, there are also heterofucans with only minor fucose components. In these polysaccharides, other monosaccharides like glucuronic acid [10] exceed the fucose content. 
It is well known that several brown seaweeds produced only one kind fucan, this not a rule and several brown seaweeds synthesize more than one kind of fucan. Using the same method described in this paper we have extracted three fucans from Dictyota mertensii [11] and Spatoglossum schröederi [10] as well as five fucans from Dictyota menstrualis [12] and Padina gymnospora [13]. In addition, other studies have shown brown seaweed synthesizing more than one fucan, including Adenocystis utricularis [14], Analipus japonicus [15], Ascophylum nodosum [16,17], Sargassum vulgare [11], Padina pavonia [18], Sargassum stenophylum [19]. Heterofucans from brown seaweed have been described since 1950 [20] and in some cases galactose was reported to be a major component $[21,12]$. Because they have not been frequently described, we decided to analyze the some biological activities of these heterofucans from $D$. delicatula.

\subsection{Anticoagulant Activity by APTT and PT Assays}

The anticoagulant properties of the heterofucans were evaluated using PT and APTT assays. No clotting inhibition was observed in PT test of any of the samples at the concentrations assayed (data not shown). On the other hand, APTT were prolonged by all the polysaccharides, in a dose-dependent manner, with regards to the control (Figure 1). The heterofucans F0.7v and F1.0v showed low anticoagulant activity while $\mathrm{F} 1.5 \mathrm{v}$ presented the most prominent anticoagulant activity with 3.8 of APTT ratio with only $0.40 \mathrm{mg} / \mathrm{mL}$ of plasma. When compared to Clexane ${ }^{\circledR}$, a low molecular weight heparin, at same concentration F1.5v presented similar anticoagulant activity $(p<0.05)$.

Fucans have a wide variety of biological activities, but their potent anticoagulant action is by far the most widely studied. The heterofucans from $D$. delicatula exhibited anticoagulant activity by APTT test only, which suggested that the sulfated polysaccharide extracted from $D$. delicatula inhibited both the intrinsic and/or common pathways of coagulation. In addition, none of the fucans from D. delicatula affected a PT test, which indicates that the extrinsic pathway of coagulation would not be inhibited or, at least, the high kinetic of the assay would not allow the detection of the anticoagulant activity of these polymers. All the fucans from $D$. delicatula showed anticoagulant activity in different levels, however there was no correlation between total sulfate content and the APTT test $\left(\mathrm{R}^{2}=0.190\right)$. Thus, the heterofucan F1.5v was the most potent anticoagulant compound, followed by F0.5v and F2.0v. In addition, F1.5v showed anticoagulant activity similar to Clexane ${ }^{\circledR}$, an anticoagulant commercial drug of reference. Our data are in agreement with several works that clearly show that the anticoagulant effect of fucans was stereo-specific and not merely a consequence of their charge density or sulfate content [22]. The position of sulfate groups on sugar residues is also very important for the anticoagulant activity of fucan. The activity relates to the concentrations of C-2 sulfate and C-2,3 disulfate [16], moreover, Silva and colleges reported that 3-O-sulfation at C-3 of 4- $\alpha$-L-fucose- $1 \rightarrow$ units was responsible for the anticoagulant activity of heterofucans from Padina gymnospora [13]. F1.5v has been selected for further bio-guided fractionation and isolation of active fractions containing potent anticoagulant fucans which will be further submitted to structural analysis in order to identify the structural features responsible for their anticoagulant activity. 
Figure 1. Anticoagulant activity of sulfated polysaccharides from Dictyopteris delicatula. Results were expressed as ratios obtained by dividing the clotting time achieved with the anticoagulant by the time achieved with the control. Hep-Heparin; Cle-Clexane ${ }^{\circledR}$ (Enoxaparin). Each value is the mean \pm SD of three determinations $(n=6){ }^{a}$ indicates a significant difference when compared with Clexane ${ }^{\circledR}$ control; ${ }^{b}$ indicates a similar APTT ratio when compared with Clexane ${ }^{\circledR}$ control.

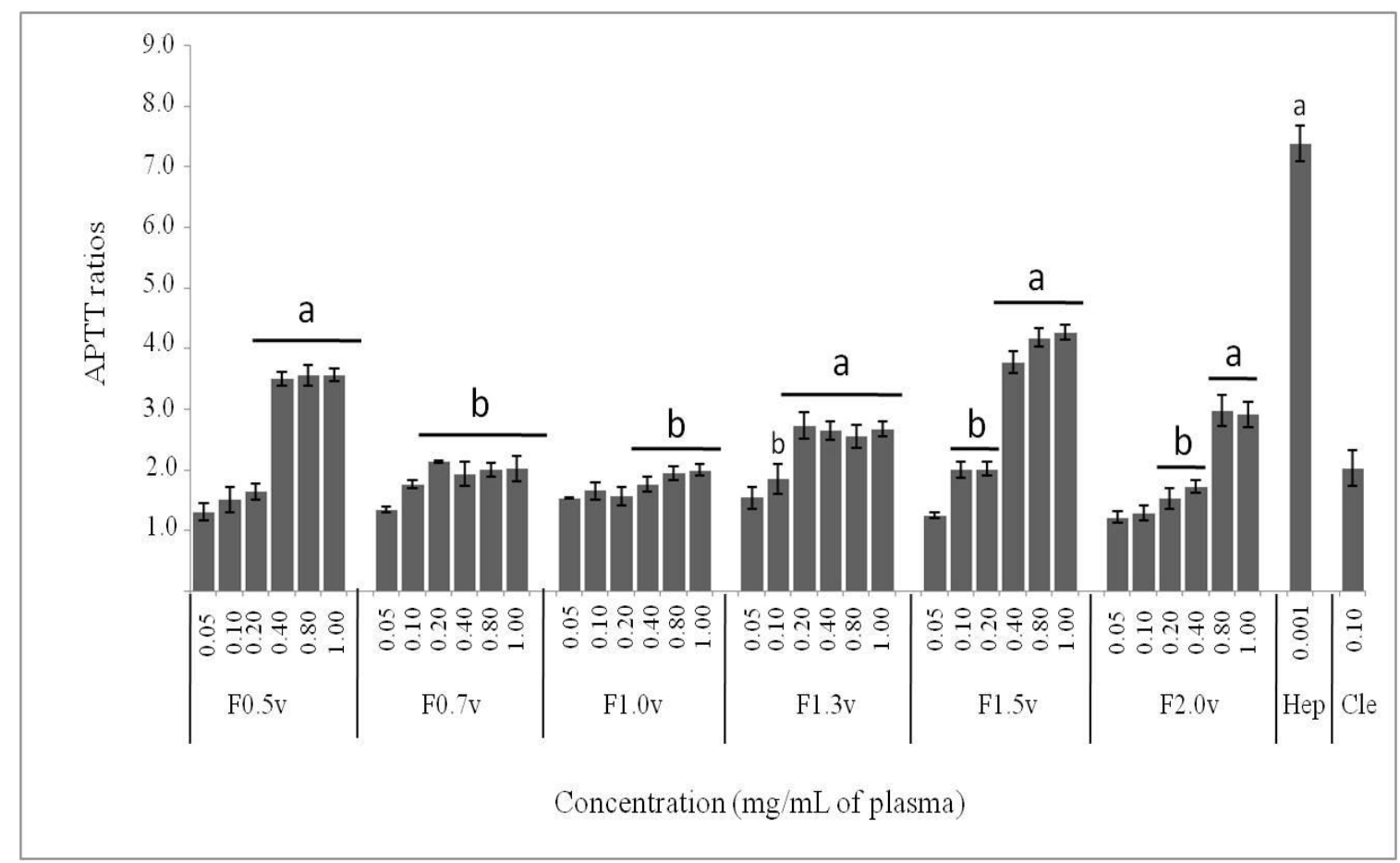

\subsection{Antioxidant Activity}

Antioxidant activity was evaluated in different assays: scavenging hydroxyl and superoxide radicals, power reducing and ferrous chelating.

Antioxidants inhibit interaction between metal and lipid through formation of insoluble metal complexes with ferrous ion or generation of steric hindrance. The iron-chelating capacity test measures the ability of antioxidants to compete with ferrozine in chelating ferrous ion. Activity is measured as the decrease in absorbance of the red $\mathrm{Fe}^{2+} /$ ferrozine complex. The plot of iron-chelating capacity as a function of sample concentration is shown in Figure 2A. The results revealed that heterofucan F1.3v did not statistically exhibit significant differences $(p>0.05)$ in ferrous chelating capacity compared with negative control (saline, data not shown), while F1.5v and F2.0v showed very low activity. On the other hand, the heterofucans F0.5v, F0.7v and F1.0v presented a dose-dependent chelating capacity. The most active compound was F0.5v with $45.5 \%$ of ferrous chelating at $1.5 \mathrm{mg} / \mathrm{mL}$. This activity was only 1.8 times lower than EDTA activity at the same concentration under the same experimental condition (Data not shown). The purification process did not increase the chelating effect of the heterofucans compared to the chelating effect of sulfated polysaccharide-rich extract from D. delicatula [9]. However, ferrous ions are considered to be the most effective pro-oxidants present in food systems [23]. Thus, the metal-chelating property of these heterofucans, mainly F0.5v and F0.7v, 
showed that they might be applied in adsorption, metal ions separation or wastewater treatment and antioxidant therapy.

Figure 2. Antioxidant activity of sulfated polysaccharides from Dictyopteris delicatula. (A) Chelating effect; (B) Power reducing assay. Each value is the mean \pm SD of three determinations. ${ }^{\text {a,b,c,d }}$ Distinct letters indicates a significant difference between sulfated polysaccharides when compared at each concentration $(p<0.05)$.
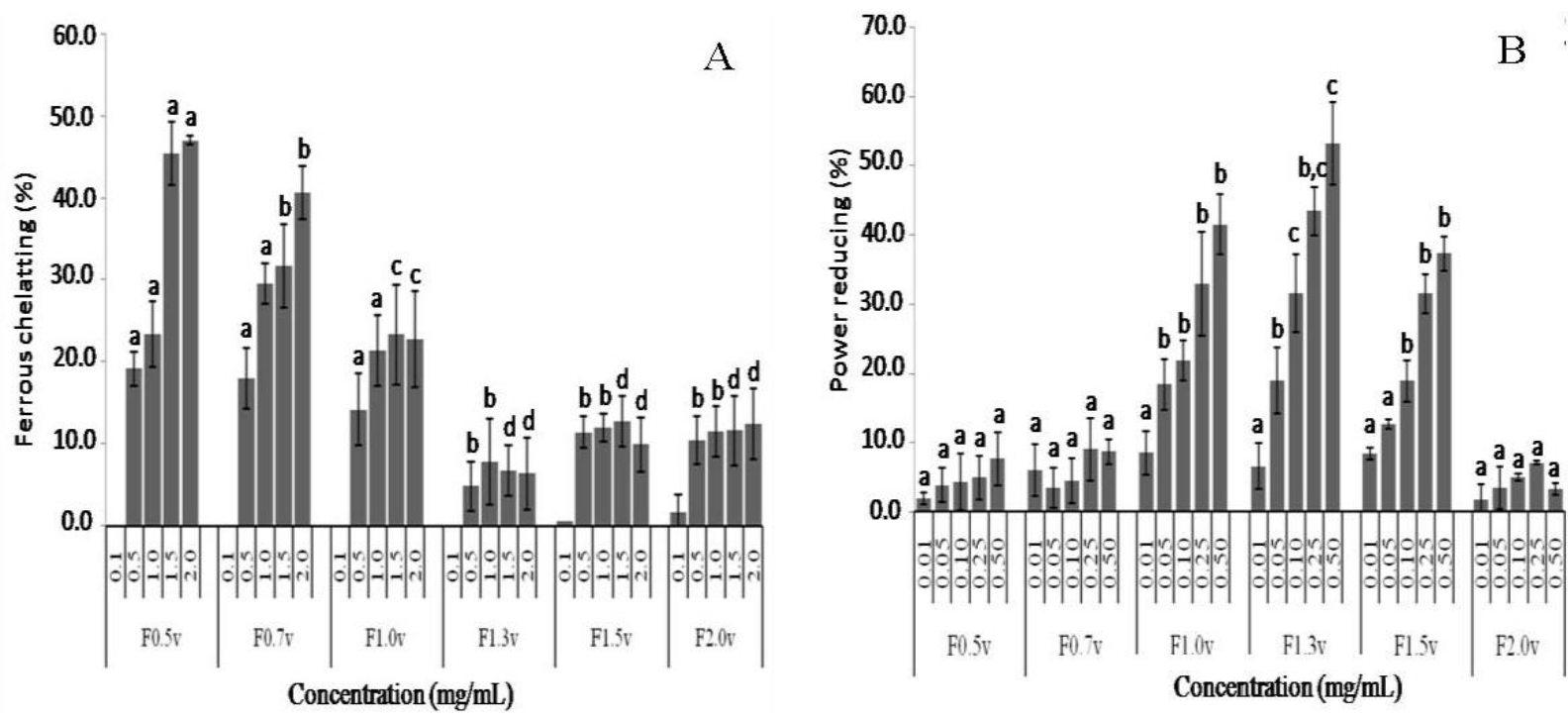

The reducing power assay was expressed as percentage activity of ascorbic acid control at $0.1 \mathrm{mg} / \mathrm{mL}$ and the data are shown in Figure 2B. Here, the heterofucans F0.5v, F0.7v and F2.0v showed extremely low activity when compared to the activity of vitamin $\mathrm{C}(0.1 \mathrm{mg} / \mathrm{mL})$. Furthermore, fucans F1.0v, F1.3v and F1.5v showed considerable reducing power, especially F1.3v, which showed $53.2 \%$ of the activity of vitamin $\mathrm{C}$ at $0.5 \mathrm{mg} / \mathrm{mL}$. It has been previously reported that there was a direct correlation between antioxidant activities and reducing power of polysaccharide. The reducing activities were usually related to the development of reductones. Reductones were reported to be terminators of free radical chain reactions by donating a hydrogen atom. In most cases, irrespective of the stage in the oxidative chain in which the antioxidant action is assessed, most nonenzymatic antioxidative activity is mediated by redox reactions [24]. Thus, several workers have reported that the antioxidant activity was concomitant with the reducing power. Zhang et al. [25] showed that acetylated polysaccharides with high donating-hydrogen abilities showed excellent reducing power, and in sulfated polysaccharides, the presence of the sulfate groups lead to the diminution of hydroxyl groups, which resulted in the descent of the reducing power. Our data showed that the most active fucan $(\mathrm{F} 1.3 \mathrm{v})$ is the fucan that has the smallest sulfate/total sugar ratio. Thus, our data indicates that the reducing power activity of the $D$. delicatula fucans studied here depends on the spatial patterns of sulfate groups, and it is unlikely to be merely a charge density effect.

Superoxide anion scavenging results in the presence of the heterofucans or commercial antioxidant are exhibited in Table 2. In this assay, the fucans F1.0v, F1.3v and F2.0v did not show superoxide scavenging activity, while F0.5v and F0.7v presented very low superoxide scavenging with 5.7 and $4.8 \%$ at $0.5 \mathrm{mg} / \mathrm{mL}$, respectively. Moreover, F1.5v was the unique polysaccharide with moderate 
superoxide radical scavenging activity $(13.4 \%$ of scavenging at $0.5 \mathrm{mg} / \mathrm{mL})$. This value is 2.4 -fold less than the superoxide activity of a rich-sulfated polysaccharide extract from $D$. delicatula obtained in previous study [9]. This suggests that sulfated polysaccharides of $D$. delicatula may act synergistically to promote a more efficient superoxide radical scavenging.

Table 2. Hydroxyl and superoxide radical scavenging activity of sulfated polyssacharides from Dictyopteris delicatula.

\begin{tabular}{|c|c|c|c|}
\hline \multirow{2}{*}{$\begin{array}{c}\text { Sulfated } \\
\text { polysaccharides }\end{array}$} & \multirow{2}{*}{$\begin{array}{c}\text { Concentration } \\
(\mathrm{mg} / \mathrm{mL})\end{array}$} & \multicolumn{2}{|c|}{ Inhibition (\%) } \\
\hline & & $\mathrm{OH}^{\circ}$ & $\mathrm{O}_{2}^{-}$ \\
\hline \multirow{4}{*}{$\mathrm{F} 0.5 \mathrm{v}$} & 0.05 & $6.1 \pm 0.7$ & $2.8 \pm 2.1$ \\
\hline & 0.1 & $9.6 \pm 0.4$ & $4.9 \pm 3.1$ \\
\hline & 0.25 & $11.0 \pm 0.9$ & $5.1 \pm 3.4$ \\
\hline & 0.5 & $14.4 \pm 2.1$ & $5.7 \pm 4.0$ \\
\hline \multirow{4}{*}{$\mathrm{F} 0.7 \mathrm{v}$} & 0.05 & $0.5 \pm 0.7$ & $3.9 \pm 0.3$ \\
\hline & 0.1 & $12.4 \pm 3.5$ & $6.1 \pm 0.9$ \\
\hline & 0.25 & $13.4 \pm 4.7$ & $6.7 \pm 3.1$ \\
\hline & 0.5 & $15.6 \pm 3.8$ & $4.8 \pm 2.4$ \\
\hline \multirow{4}{*}{$\mathrm{F} 1.0 \mathrm{v}$} & 0.05 & $6.6 \pm 3.1$ & $0 \pm 0$ \\
\hline & 0.1 & $12.7 \pm 2.9$ & $0 \pm 0$ \\
\hline & 0.25 & $16.9 \pm 2.2$ & $0 \pm 0$ \\
\hline & 0.5 & $17.0 \pm 3.4$ & $0 \pm 0$ \\
\hline \multirow{4}{*}{$\mathrm{F} 1.3 \mathrm{v}$} & 0.05 & $0 \pm 0$ & $0 \pm 0$ \\
\hline & 0.1 & $0 \pm 0$ & $0 \pm 0$ \\
\hline & 0.25 & $0 \pm 0$ & $0 \pm 0$ \\
\hline & 0.5 & $0 \pm 0$ & $0 \pm 0$ \\
\hline \multirow{4}{*}{$\mathrm{F} 1.5 \mathrm{v}$} & 0.05 & $0 \pm 0$ & $3.9 \pm 2.1$ \\
\hline & 0.1 & $0 \pm 0$ & $4.9 \pm 3.1$ \\
\hline & 0.25 & $0 \pm 0$ & $9.6 \pm 3.4$ \\
\hline & 0.5 & $0 \pm 0$ & $13.4 \pm 2.1$ \\
\hline \multirow{7}{*}{$\mathrm{F} 2.0 \mathrm{v}$} & 0.05 & $0 \pm 0$ & $0 \pm 0$ \\
\hline & 0.1 & $0 \pm 0$ & $0 \pm 0$ \\
\hline & 0.25 & $0 \pm 0$ & $0 \pm 0$ \\
\hline & 0.5 & $0 \pm 0$ & $0 \pm 0$ \\
\hline & 0.1 & $43.6 \pm 2.4$ & $41.8 \pm 4.7$ \\
\hline & 0.25 & $64.3 \pm 3.0$ & $72.1 \pm 2.9$ \\
\hline & 0.5 & $93.7 \pm 3.7$ & $86.3 \pm 3.1$ \\
\hline
\end{tabular}

We determined the hydroxyl radical scavenging activity of the heterofucans of $D$. delicatula. Table 2 depicts the results obtained for the inhibition of hydroxyl radical formation. Only the sulfated polysaccharides F0.5v, F0.7v and F1.0v have shown activity in hydroxyl radical scavenging. However, these polysaccharides showed moderate activity with scavenging activity of $14.4 \%, 15.6 \%$ and $17.0 \%$, respectively, at $0.5 \mathrm{mg} / \mathrm{mL}$. For this assay, gallic acid showed $93.7 \%$ radical scavenging effect at $0.5 \mathrm{mg} / \mathrm{mL}$ concentration. 
In this work, all the polysaccharides from $D$. delicatula were poor effective hydroxyl radical scavengers, which is unsurprising, since the most of the sulfated polysaccharides reported in the literature have a weak hydroxyl radical scavenger activity [22]. However, heterofucans from Padina gymnospora [26], which have similar monosaccharide composition of fucans from $D$. delicatula, as well as, homofucans from Fucus vesiculosus and Laminaria japonica [26,27] have high activity as hydroxyl radical scavengers.

The results reported here are very interesting, since they indicate that brown seaweed $D$. delicatula synthesizes heterofucans with different antioxidant mechanisms. Although their antioxidant potential was not significantly high in some assays, the sum of individual effects of these polymers should be used as a defense strategy of this seaweed. This would supply a more efficient defense against free radicals.

\subsection{Antiproliferative Activity}

The viability of HeLa cells treated with sulfated polysaccharides for $24 \mathrm{~h}$ was determined using a colorimetric MTT-based assay (Figure 3). Initially, the antiproliferative activity of sulfated polysaccharides was evaluated in a single concentration, $2.0 \mathrm{mg} / \mathrm{mL}$. F2.0v showed the lowest activity inhibiting only $14.1 \%$ of cell viability. The best antiproliferative activity was found with F1.3v and F0.7v that inhibit $91.8 \%$ and $60.0 \%$ of HeLa cells proliferation, respectively (Figure 3A). Thus, the antiproliferative activity of these fucans was evaluated at different concentrations.

Figure $3 \mathrm{~B}$ demonstrates that this effect of fucan $\mathrm{F} 0.7 \mathrm{~V}$ is a dose-dependent effect, reaching the saturation around $0.4 \mathrm{mg} / \mathrm{mL}$. In addition, it showed higher antiproliferative activity than $\mathrm{F} 1.3 \mathrm{v}$ in low concentration (from 0.1 to $0.6 \mathrm{mg} / \mathrm{mL}$ ). The heterofucan $\mathrm{F} 1.3 \mathrm{v}$ also showed a dose-dependent antiproliferative activity, reaching the saturation around $2.0 \mathrm{mg} / \mathrm{mL}$. However, its activity was much higher than F0.7v inhibiting almost $100 \%$ of HeLa cell proliferation.

Earlier, we demonstrated a polysaccharide-rich extract from D. delicatula inhibiting Hela proliferation in a dose-dependent manner, reaching the saturation around $2.0 \mathrm{mg} / \mathrm{mL}(\sim 61 \%)$ [9]. When we purified the fucans from this seaweed, it was clear that the fucan F1.3v was the most responsible for antiproliferative activity of the polysaccharide-rich extract from $D$. delicatula, since this fucan inhibited almost $100 \%$ HeLa proliferation. There have been a number of studies on the antitumor activity of fucan in vivo and in vitro [5,6,22,28]. Although the precise mechanisms underlying this activity remain to be determined, a few possibilities have been proposed. Fucan is speculated to act by inhibiting tumor angiogenesis modulating host immune systems [22], arresting the cell cycle, and/or inducing apoptosis [29]. From the experiment carried out here it was clear that the mechanism of action of $\mathrm{F} 1.3 \mathrm{v}$ is directly on the HeLa cell. Further studies will clarify the antiproliferative mechanism of fucan F1.3v. 
Figure 3. Influence of sulfated polysaccharides from Dictyopteris delicatula on inhibition of cell proliferation of HeLa cells after $72 \mathrm{~h}$ incubation: (A) Antiproliferative activity of sulfated polysaccharides at concentration of $2.0 \mathrm{mg} / \mathrm{mL}$; (B) Dose-dependent effect of sulfated polysaccharides. Each value is the mean \pm SD of seven determinations. Different letters indicates a significant difference between concentrations of individual sulfated polysaccharides $(p<0.05)$; the asterisk indicates a significant difference between different sulfated polysaccharides at same concentration $(p<0.05)$.

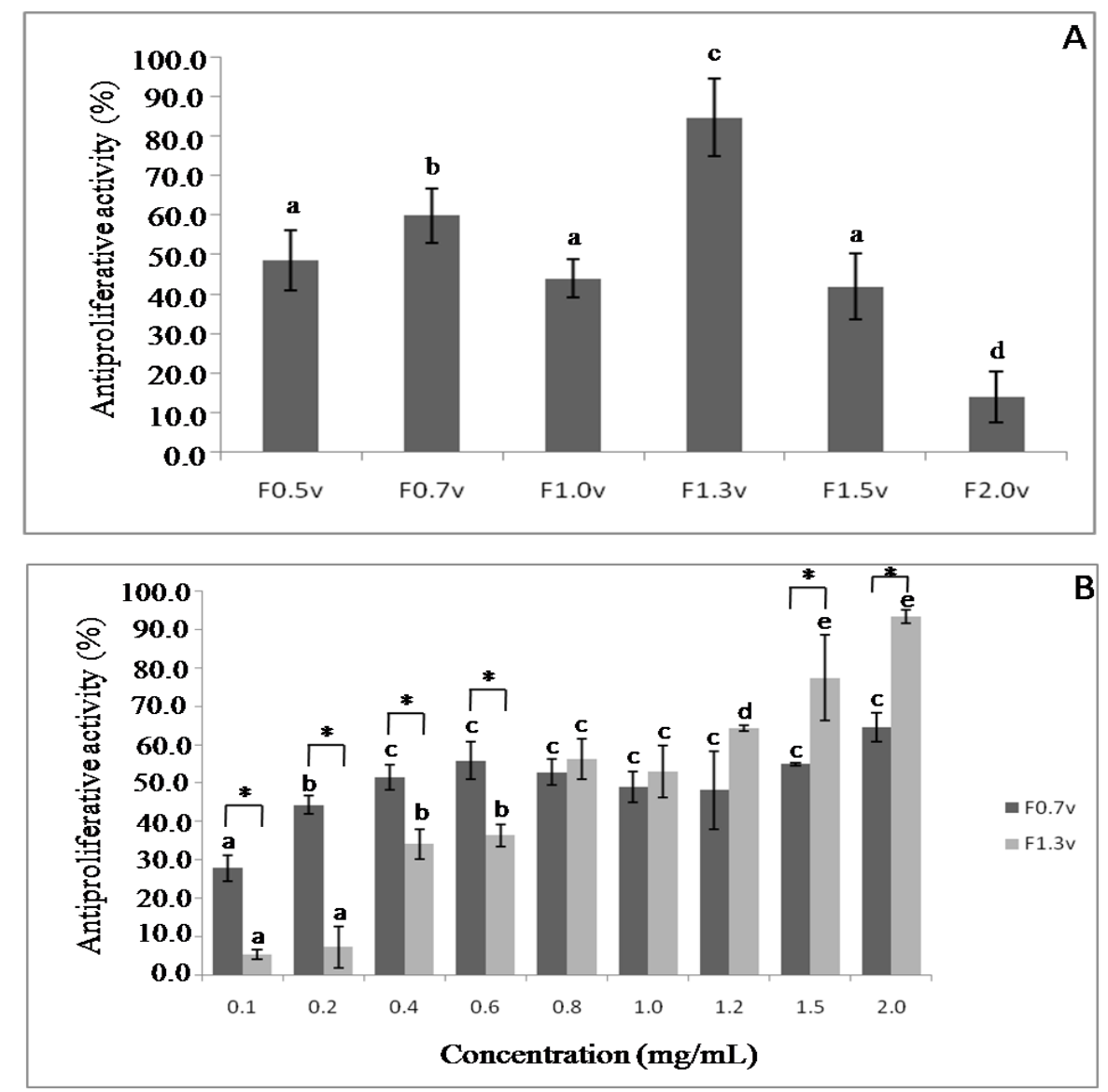

\section{Experimental Section}

\subsection{Materials}

Arabinose, mannose, galactose, xylose, fucose, glucuronic acid and unfractionated heparin were obtained from Sigma (St. Louis, MO, USA). Acetone and sulfuric acid were obtained from Merck (Darmstadt, Germany). Clexane ${ }^{\circledR}$ (enoxaparin) was purchased from Aventis (São Paulo, Brazil).

\subsection{Extraction of Polysaccharides}

The marine alga Dictyopteris delicatula Lamouroux was collected in the sub littoral of Natal, RN, Brazil. The extraction of sulfated polysaccharide followed the procedure described by Rocha et al. [30]. Immediately after collection, the seaweed was dried at $50{ }^{\circ} \mathrm{C}$ under ventilation and ground in a blender. Next, it was treated with acetone to eliminate lipids and pigments. One hundred grams of defatted, dried, and powdered alga were suspended in $500 \mathrm{~mL}$ of $0.25 \mathrm{M} \mathrm{NaCl}$, and the $\mathrm{pH}$ 
was adjusted to 8.0 with $\mathrm{NaOH}$. Twenty milligrams of maxatase, an alkaline protease from Esporobacillus (Biobras, MG, Brazil), was added to the mixture for proteolytic digestion. After $18 \mathrm{~h}$ of incubation at $60^{\circ} \mathrm{C}$ under agitation, the mixture was filtered through cheesecloth. The filtrate, which is the $D$. delicatula' polysaccharide-rich extract, was fractionated by acetone precipitation as follows: 0.5 volumes of ice-cold acetone was added to the solution under gentle agitation and maintained at $4{ }^{\circ} \mathrm{C}$ for $24 \mathrm{~h}$. The precipitate formed was collected by centrifugation $(10.000 \times \mathrm{g}, 20 \mathrm{~min})$, vacuum dried, resuspended in distilled water, and analyzed. The operation was repeated by adding $0.7,1.0,1.3$, 1.5 and 2.0 volumes of acetone to the supernatant. These fractions were further purified by molecular sieving in Sephadex G-100 $(140 \times 2.6 \mathrm{~cm})$. About $200 \mathrm{mg}$ of each fraction, dissolved in $2 \mathrm{~mL}$ of water, was applied to the column and eluted with a solution of $0.2 \mathrm{M}$ acetic acid and $0.15 \mathrm{M} \mathrm{NaCl}$, and fractions of $1 \mathrm{~mL}$ were collected and assayed by the phenol/ $\mathrm{H}_{2} \mathrm{SO}_{4}$ reaction [31] and by metachromatic assay using 1,9-dimethylmethylene blue [32]. The fractions containing the sulfated polysaccharides were pooled, dialyzed against distilled water, and lyophilized.

\subsection{Chemical Analysis and Monosaccharide Composition}

Total sugars were estimated by the phenol- $\mathrm{H}_{2} \mathrm{SO}_{4}$ reaction [31] using L-fucose as standard. Sulfate content was determined according to the gelatin-barium method [33], using sodium sulfate $(1 \mathrm{mg} / \mathrm{mL})$ as standard and after acid hydrolysis of the polysaccharides $\left(4 \mathrm{M} \mathrm{HCl}, 100{ }^{\circ} \mathrm{C}, 6 \mathrm{~h}\right)$. Protein content was measured using Spector's method [34].

The polysaccharides were hydrolyzed with $0.5,1,2$, and $4 \mathrm{M}$ of $\mathrm{HCl}$, respectively, for various lengths of time $(0.5,1,2$ and $4 \mathrm{~h})$ at $100{ }^{\circ} \mathrm{C}$. Reducing sugars were determined using the Somogyi-Nelson method [35]. After acid hydrolysis, sugar composition was determined by a LaChrom Elite ${ }^{\circledR}$ HPLC system from VWR-Hitachi with a refractive index detector (RI detector model L-2490). A LichroCART ${ }^{\circledR} 250-4$ column $(250 \mathrm{~mm} \times 40 \mathrm{~mm})$ packed with Lichrospher ${ }^{\circledR} 100 \mathrm{NH}_{2}(5 \mu \mathrm{m})$ was coupled to the system. The sample mass used was $0.2 \mathrm{mg}$ and analysis time was $25 \mathrm{~min}$. The following sugars were analyzed as references: arabinose, fructose, fucose, galactose, glucose, glucosamine, glucuronic acid, mannose, and xylose. The amount of uronic acid was determinate as described by Leite et al. [10].

\subsection{Anticoagulant Activity}

All the Protrombin Time (PT) and Activated Partial Thromboplastin Time (APTT) coagulation assays were performed with a coagulometer as described earlier [12] and measured using citrate-treated normal human plasma. All assays were performed in duplicate and repeated at least three times on different days $(n=6)$. The results were expressed as APTT ratio, which was determined as follows: APTT control time/APTT sample time.

\subsection{Antioxidant Activity}

To analyze the antioxidant activity of the sulfated polysaccharides obtained, three assays were performed: hydroxyl radical scavenging, superoxide radical scavenging, and ferric chelating, as described previously [9]. 


\subsubsection{Hydroxyl Radical Scavenging Activity Assay}

The scavenging activity of seaweed sulfated polysaccharides against the hydroxyl radical was investigated using Fenton's reaction $\left(\mathrm{Fe}^{2+}+\mathrm{H}_{2} \mathrm{O}_{2} \rightarrow \mathrm{Fe}^{3+}+\mathrm{OH}^{-}+\mathrm{OH}\right)$. These results were expressed as an inhibition rate. Hydroxyl radicals were generated using a modified method [17] in $3 \mathrm{~mL}$ sodium phosphate buffer $(150 \mathrm{mM}, \mathrm{pH} 7.4)$, which contained $10 \mathrm{mM} \mathrm{FeSO} \cdot 7 \mathrm{H}_{2} \mathrm{O}, 10 \mathrm{mM}$ EDTA, $2 \mathrm{mM}$ sodium salicylate, $30 \% \mathrm{H}_{2} \mathrm{O}_{2}(200 \mu \mathrm{L})$ and varying sulfated polysaccharide concentration. In the control, a sodium phosphate buffer replaced $\mathrm{H}_{2} \mathrm{O}_{2}$. The solutions were incubated at $37^{\circ} \mathrm{C}$ for $1 \mathrm{~h}$, and the presence of the hydroxyl radical was detected by monitoring absorbance at $510 \mathrm{~nm}$.

\subsubsection{Superoxide Radical Scavenging Activity Assay}

The assay was based on the capacity of sulfated polysaccharides to inhibit the photochemical reduction of nitroblue tetrazolium (NBT) in the riboflavin-light-NBT system. Each $3 \mathrm{~mL}$ reaction mixture contained $50 \mathrm{mM}$ phosphate buffer ( $\mathrm{pH} 7.8$ ), $13 \mathrm{mM}$ methionine, $2 \mu \mathrm{M}$ riboflavin, $100 \mu \mathrm{M}$ EDTA, NBT $(75 \mu \mathrm{M})$, and $1 \mathrm{~mL}$ sample solution. The production of blue formazan was followed by monitoring the increase in absorbance at $560 \mathrm{~nm}$ after $10 \mathrm{~min}$ illumination from a fluorescent lamp. The entire reaction assembly was enclosed in a box lined with aluminum foil. Identical tubes with the reaction mixture were kept in the dark and served as blanks.

\subsubsection{Ferric Chelating}

The ferrous ion chelating ability of samples was investigated according to previous studies [9]. Briefly, the reaction mixture, containing samples of $\mathrm{FeCl}_{2}(0.05 \mathrm{~mL}, 2 \mathrm{mM})$ and ferrozine $(0.2 \mathrm{~mL}$, $5 \mathrm{mM}$ ), was well shaken and incubated for $10 \mathrm{~min}$ at room temperature. The absorbance of the mixture was measured at $562 \mathrm{~nm}$ against a blank.

\subsection{Cell Proliferation Studies}

HeLa cells were grown in $75 \mathrm{~cm}^{2}$ flasks in DMEM medium. Cells were seeded into 96-well plates at a density of $5 \times 10^{3}$ cell/well and allowed to attach overnight in $300 \mu \mathrm{L}$ medium incubated at $37{ }^{\circ} \mathrm{C}$, $5 \% \mathrm{CO}_{2}$. The sulfated polysaccharides fractions were added at a final concentration of $0.01 ; 0.1 ; 1.0$ and $2.0 \mathrm{mg} / \mathrm{mL}$, for $72 \mathrm{~h}$ at $37{ }^{\circ} \mathrm{C}$ and $5 \% \mathrm{CO}_{2}$. After incubation, traces of sulfated polysaccharides fractions were removed by washing the cells twice with $200 \mu \mathrm{L}$ PBS and applying $100 \mu \mathrm{L}$ of fresh medium plus and $10 \mu \mathrm{L}$ of $12 \mathrm{mM}$ MTT dissolved in PBS to determine the effects of the algal sulfated polysaccharides on cell proliferation. Cells were then incubated for $4 \mathrm{~h}$ at $37{ }^{\circ} \mathrm{C}, 5 \% \mathrm{CO}_{2}$. In order to solubilize the product of MTT cleavage, $100 \mu \mathrm{L}$ of isopropanol containing $0.04 \mathrm{M} \mathrm{HCl}$ was added to each well and thoroughly mixed using a multichannel pipettor. Within $1 \mathrm{~h}$ of HCl-isopropanol addition, the absorbance at $570 \mathrm{~nm}$ was read using a Multiskan Ascent Microplate Reader (Thermo Labsystems, Franklin, MA). The percent inhibition of cell proliferation was calculated as follows:

$$
\% \text { Inhibition }=\frac{\text { Abs. } 570 \mathrm{~nm} \text { control }- \text { Abs. } 570 \mathrm{~nm} \text { sample }}{\text { Abs. } 570 \mathrm{~nm} \text { control }} \times 100
$$

Each concentration of the respective sulfated polysaccharide was assayed in seven-fold. 


\subsection{Statistical Analysis}

All data were expressed as mean \pm standard deviation. Statistical analysis was done by one-way ANOVA using the SIGMAStat version 2.01 computer software. Student-Newmans-Keuls post-tests were performed for multiple group comparison. In all cases statistical significance was set at $p<0.05$.

\section{Conclusions}

In conclusion, we have extracted six heterofucans from the brown seaweed $D$. delicatula which showed anticoagulant, antioxidant and antiproliferative activities at different levels of activity. However, it has become clear that at least some of these activities are not merely an effect of high charge density but have distinct structural specificities. Future conformational studies of well-defined fucan structures should lead to a better understanding of the biological properties of these fucans.

\section{Acknowledgements}

We wish to thank CNPq, CAPES and MCT for their financial support in the form of grants and fellowship awards. KD Magalhaes, RM Oliveira, RBG Camara, GP Fidelis, LTDB Nobre, SL Cordeiro, MSSP Costa, DA Sabry and N D-Santos thank CNPq and CAPES for fellowship support.

\section{References}

1. Barroso, E.M.A.; Costa, L.S.; Medeiros, V.P.; Cordeiro, S.L.; Costa, M.S.S.P.; Franco, C.R.C.; Nader, H.B.; Leite, E.L. A non-anticoagulant heterofucan has antithrombotic activity in vivo. Planta Med. 2008, 74, 712-718.

2. Rocha, H.A.O.; Franco, C.R.C.; Trindade, E.S.; Carvalho, L.C.M.; Veiga, S.S.; Leite, E.L.; Dietrich, C.P.; Nader, H.B. A fucan from the brown seaweed Spatoglossum schröederi inhibits Chinese hamster ovary cell adhesion to several extracellular matrix proteins. Braz. J. Med. Biol. Res. 2001, 34, 621-626.

3. Hyun, J.H.; Kim, S.C.; Kang, J.I.; Kim, M.K.; Boo, H.J.; Kwon, J.M.; Koh, Y.S.; Hyun, J.W.; Park, D.B.; Yoo, E.S.; Kang, H.K. Apoptosis inducing activity of fucoidan in HCT-15 colon carcinoma cells. Biol. Pharm. Bull. 2009, 32, 1760-1764.

4. Ohta, Y.; Lee, J.B.; Hayashi, H.; Hayashi, T. Isolation of galactan from Codium fragile and its antiviral effects. Biol. Pharm. Bull. 2009, 32, 892-898.

5. Bilan, M.I.; Usov, A.I. Structural analysis of fucoidans. Nat. Prod. Commun. 2008, 3, 1639-1648.

6. Jiao, G.; Yu, G.; Zhang, J.; Ewart, H.S. Chemical structures and bioactivities of sulfated polysaccharides from marine algae. Mar. Drugs 2011, 9, 196-223.

7. Michel, G.; Nyval-Collen, P.; Barbeyron, T.; Czjzek, M.; Helbert, W. Bioconversion of red seaweed galactans: a focus on bacterial agarases and carrageenases. Appl. Microbiol. Biotechnol. 2006, 71, 23-33.

8. Cunha, P.L.R.; Paula, R.C.M.; Feitosa, J.P.A. Polysaccharides from brazilian biodiversity: An opportunity to charge knowledge into economic value. Quim. Nova 2009, 32, 649-660. 
9. Costa, L.S.; Fidelis, G.P.; Cordeiro, S.L.; Oliveira, R.M.; Sabry, D.A; Câmara, R.B.G.; Nobre, L.T.D.B.; Costa, M.S.S.P.; Almeida-Lima, J.; Farias, E.H.C.; Leite, E.L.; Rocha, H.A.O. Biological activities of sulfated polysaccharides from tropical seaweeds. Biomed. Pharmacother. 2010, 64, 21-28.

10. Leite, E.L.; Medeiros, M.G.L.; Rocha, H.A.O.; Farias, G.G.M.; Silva, L.F.; Chavante, S.F.; Abreu, L.D.; Dietrich, C.P.; Nader, H.B. Structure and pharmacological activities of a sulfated xylofucoglucuronan from the alga Spatoglossum schröederi. Plant Sci. 1998, 132, 215-228.

11. Dietrich, C.P.; Farias, G.G.M.; Abreu, L.R.D.; Leite, E.L.; Silva, L.F.; Nader, H.B. A new approach for characterization of polysaccharides from algae: Presence of four main acidic polysaccharides in three specie of the class Phaeophycea. Plant Sci. 1995, 108, 143-153.

12. Albuquerque, I.R.L; Queiroz, K.C.S.; Alves, L.G.; Santos, E.A.; Leite, E.L.; Rocha, H.A.O. Heterofucans from Dictyota menstrualis have anticoagulant activity. Braz. J. Med. Biol. Res. 2004, 37, 167-171.

13. Silva, T.M.A.; Alves, L.G.; Queiroz, K.C.S.; Santos, M.G.L.; Marques, C.T.; Chavante, S.F.; Rocha, H.A.O; Leite, E.L. Partial characterization and anticoagulant activity of a heterofucan from the brown seaweed Padina gymnospora. Braz. J. Med. Biol. Res. 2005, 38, 523-533.

14. Ponce, N.M.A.; Pujol, C.A.; Damonte, E.B. Fucoidans from the brown seaweed Adenocystis utricularis: Extraction methods, antiviral activity and structural studies. Carbohydr. Res. 2003, 338, 153-165.

15. Bilan, M.I.; Zakharova, A.N.; Grachev, A.A.; Shashkov, A.S.; Nifant'ev, N.E.; Usov, A.I. Polysaccharides of algae: 60. Fucoidan from the Pacific brown alga Analipus japonicus (Harv.) Winne (Ectocarpales, Scytosiphonaceae). Russ. J. Bioorg. Chem. 2007, 33, 44-53.

16. Chevolot, L.; Mulloy, B.; Ratiskol, J.; Foucault, A.; Colliec-Jouault, S. A disaccharide repeat unit is the structure in fucoidans from two species of brown algae. Carbohydr. Res. 2001, 330, 529-535.

17. Marais, M.F.; Joseleau, J.P. A fucoidan fraction from Ascophyllum nodosum. Carbohydr. Res. 2001, 336, 155-159.

18. Hussein, M.M.; Abdel, A.; Salem, H.M. Sulfated heteropolysaccharides from Padina pavoia. Phytochemistry 1980, 19, 2131-2132.

19. Duarte, M.E.R.; Cardoso, M.A.; Noseda, M.D.; Cerezo, A.S. Structural studies on fucoidans from the brown seaweed Sargassum stenophyllum. Carbohydr. Polym. 2001, 333, 281-293.

20. Kloareg, B.; Quatrano, R.S. Structure of cell wall of marine algae and ecophysiological function of matrix polysaccharides. Oceanogr. Mar. Biol. Annu. Rev. 1988, 26, 259-315.

21. Nishino, T.; Nishioka, C.; Ura, H.; Nagumo, T. Isolation and partial characterization of a novel amino sugar-containing fucan sulfate from commercial Fucus vesiculosus sulfated fucan. Carbohydr. Res. 1994, 255, 213-224.

22. Li, B.; Lu, F.; Wei, X.; Zhao, R. Fucoidan: Structure and bioactivity. Molecules 2008, 13, 1671-1695.

23. Cuzzocrea, S.; Riley, D.P.; Caputi, A.P.; Salvemini, D. Antioxidant therapy: A new pharmacological approach in shock, inflammation and ischemia/reperfusion injury. Pharmacol. Rev. 2001, 53, 135-159. 
24. Kaeffer, B.; Benard, C.; Lahaye, M.; Blottiere, H.M.; Cherbut, C. Biological properties of ulvan, a new source of green seaweed sulfated polysaccharides, on cultured normal and cancerous colonic epithelial cells. Planta Med. 1999, 65, 527-531.

25. Zhang, Z.; Zhang, Q.; Wang, J.; Song, H.; Zhang, H.; Niu, X. Chemical modification and influence of function groups on the in vitro-antioxidant activities of porphyran from Porphyra haitanensi. Carbohydr. Polym. 2010, 79, 290-295.

26. Souza, M.C.R.; Marques, C.T.; Dore, C.M.G.; Silva, F.R.F.; Rocha, H.A.O.; Leite, E.L. Antioxidant activities of sulfated polysaccharides from brown and red seaweeds. J. Appl. Psychol. 2007, 19, 153-160.

27. Wang, J.; Zhang, Q.; Zhang, Z.; Li, Z. Antioxidant activity of sulfated polysaccharide fractions extracted from Laminaria japonica. Int. J. Biol. Macromol. 2008, 42, 127-132.

28. Holtkamp, A.D.; Kelly, S.; Ulber, R.; Lang, S. Fucoidans and fucoidanases-Focus on techniques for molecular structure elucidation and modification of marine polysaccharides. Appl. Microbiol. Biotechnol. 2009, 82, 1-11.

29. Ye, J.; Li, Y.; Teruya, K.; Katakura, Y.; Ichikawa, A.; Eto, H.; Hosoi, M.; Hosoi, M.; Nishimoto, S.; Shirahata, S. Enzyme-digested fucoidan extracts derived from seaweed Mozuku of Cladosiphon novae-caledoniae Kylin inhibit invasion and angiogenesis of tumor cells. Cytotechnology 2005, 47, 117-126.

30. Rocha, H.A.O.; Moraes, F.A.; Trindade, E.S.; Franco, C.R.C.; Torquato, R.J.S.; Veiga, S.S.; Valente, A.P.; Mourão, P.A.S.; Leite, E.L.; Nader, H.B.; Dietrich, C.P. Structural and hemostatic activities of a sulfated galactofucan from the brown alga Spatoglossum schroederi-An ideal antithrombotic agent? J. Biol. Chem. 2005, 280, 41278-41288.

31. Dubois, M.; Gilles, K.A.; Hamilton, J.K.; Rebers, P.A.; Smith, F. Colorimetric method for determination of sugars and related substances. Anal. Chem. 1956, 28, 250-256.

32. Farndale, R.W., Buttle, D.J., Barrett, A.J. Improved quantitation and discrimination of sulphated glycosaminoglycans by use of dimethylmethylene blue. Biochim. Biophys. Acta 1986, 883, 173-177.

33. Dodgson, K.S.; Price, R.G. A note on the determination of the ester sulphate content of sulphated polysaccharides. Biochem. J. 1962, 84, 106-110.

34. Spector, J. Refinement of the coomassie blue method of protein qualification. A simple and linear spectrofotometric assay of 0.5 to $50 \mu \mathrm{g}$ of protein. Anal. Biochem. 1978, 86, 142-146.

35. Somogyi, M. Notes on sugar determination. J. Biol. Chem. 1952, 195, 19-23.

(C) 2011 by the authors; licensee MDPI, Basel, Switzerland. This article is an open access article distributed under the terms and conditions of the Creative Commons Attribution license (http://creativecommons.org/licenses/by/3.0/). 